\title{
CHARACTERISTICS OF DISPUTE RESOLUTION IN WETLAND ENVIRONMENT
}

https://doi.org/10.47743/jopafl-2021-19-19

\author{
Mulyani ZULAEHA \\ Faculty of Law, Lambung Mangkurat University, Banjarmasin, \\ South Kalimantan, Indonesia \\ mulyani.zulaeha@outlook.com \\ Suprapto \\ Faculty of Law, Lambung Mangkurat University, Banjarmasin, \\ South Kalimantan, Indonesia \\ Linda NURULITA \\ Faculty of Law, Lambung Mangkurat University, Banjarmasin, \\ South Kalimantan, Indonesia \\ Rizka Annisa FALMELIA \\ Faculty of Law, Lambung Mangkurat University, Banjarmasin, \\ South Kalimantan, Indonesia
}

\begin{abstract}
The purpose of this research is to study and analyze the characteristics of dispute resolution in a wetland environment through the integration of environmental aspects, culture and empowerment of rural communities. A life that is safe, orderly and peaceful, is the life of a human society, so that every dispute needs to be resolved. In fact, the principle of justice is simple, fast and low cost for most of the people. This research method uses a socio-juridical (socio-legal) approach using an interdisciplinary or "hybrid" approach between aspects of normative legal research with a sociological approach using qualitative analysis. Through the settlement of disputes based on deliberation to reach consensus (badamai) based on local wisdom that grows and develops in communities in wetland areas, it is hoped that it will be able to expand access to justice in rural communities and reduce the burden of cases on formal channels. This requires a forum as an institution that facilitates the settlement of disputes outside the court at the village level.
\end{abstract}

Keywords: Characteristics, Dispute Resolution, Wetland Environment.

\section{Introduction}

A dispute is a legal phenomenon, every dispute requires resolution action, there are two dispute resolution mechanisms, namely the litigation channel or through the court and the non-litigation channel or outside the court through deliberation / peace. Dispute resolution is often carried out outside the formal channels by means of deliberation and consensus and refers to the values of customary law and religion. In societies where kinship and group relations are still strong and still adhere to customs, the choice of dispute or conflict resolution is directed at non-formal methods through the cultural approach of deliberation or consensus (mediation). This is done because dispute resolution is 
interpreted as an effort to maintain order and implementation of spiritual values that exist in society. At the village government level, through Law Number 6 of 2014 concerning Villages, it affirms the function of the village head as resolving village community disputes. Article 26 (1) states: "The Village Head is tasked with organizing Village Government, implementing Village Development, developing Village community, and empowering Village communities”. Furthermore, Article 26 (4) letter k. states: "In carrying out the tasks referred to in paragraph (1), the Village Head is obliged to: resolve community disputes in the Village." In connection with the above problems, it is necessary to put forward the urgency of village empowerment in the context of strengthening institutions in resolving community disputes. In a development perspective based on local capabilities. The essence of community empowerment basically places the community at the center of attention as well as being seen and positioned as a subject in the development process. The community is a figure that is intact, active, has the ability to think, will and try. With regard to dispute resolution that occurs in the community, mediation tends to be chosen because it is cheaper, faster, and more accessible than the litigation route. The ease of public access, is instant, relatively restoring harmony in society as a prominent force. Mediation is not new, from generation to generation, the customs of the community have carried out efforts to resolve disputes by deliberation to reach a consensus. The Banjar tribe, which are generally located in wetland areas, namely riverbanks, settlement of disputes with the Badamai custom as local wisdom has long been applied hereditary and was formalized during the period of the Banjar Kingdom in the Sultan Adam Law. If it is related to the obligation of the Village Head to resolve community disputes in the Village as referred to in Article 26 and Article 28 of the Village Law, as well as efforts to empower villages through strengthening the Badamai system as an alternative to dispute resolution, it is important to study and analyze the characteristics of dispute resolution in the wetland environment through integration between environmental aspects, culture and empowerment of rural communities.

\section{Research methods}

This research method uses a socio-juridical (socio-legal) approach using an interdisciplinary or "hybrid" approach between aspects of normative legal research with a sociological approach using qualitative analysis, namely by analyzing data in depth and holistically to study and analyze the characteristics of dispute resolution. in the wetland environment through the integration of environmental aspects, culture and empowerment of village communities, so that in the end we can examine the suitability of das sollen and das sein. This is to fulfill the need for a more detailed and accurate explanation of legal issues in a more meaningful way by making a comparison between the law in book and the law in action (Fetterman, 1998).

\section{Results and discussion}

The out-of-court dispute resolution model is currently a way of resolving disputes that are being promoted, this is in accordance with the policy direction and legal development strategy contained in Presidential Regulation No.2 of 2015 concerning the National Medium-Term Development Plan through the implementation of an easy and easy 
Civil Law System Reform. fast especially civil law enforcement. Settlement of civil cases carried out by encouraging the optimization of the mediation process in court and simplifying civil case procedures is expected to encourage settlement efficiency, especially civil cases. Peace is the energy from within humans, which is owned by everyone. Therefore, peace is built through honesty, a life of sharing, mutual respect and respect for each other. All that can happen if done sincerely, without intrigue and self-interest. "Peace is beautiful". We often hear this slogan which is even used as a motto to encourage harmony between people. Peace has many meanings. Peace can mean a state of calm. Peace can also describe the emotional state within. Peace can also be interpreted as a harmony in the natural life between humans where there is no enmity or conflict. The conception of peace is basically the same in every region, except that the term or designation differs according to certain cultures and environments. However, in simple terms, peace in social life can mean the absence of violence, harmony and a system of justice that applies both to individuals and in the social and political justice system as a whole. Peace involves thinking patterns, ways of behaving, behavior, character, mentality, beliefs, patterns of relationships with other parties, an order of living together which is marked by noble values such as justice, equality, democracy and solidarity. Culture of peace (culture of peace) concerns how we organize a new social life free from violence and oppression. A culture of peace is a set of values, attitudes, behaviors and a way of life that respects life and human rights, tolerance and solidarity. The culture of peace is peace that is manifestly reflected in everyday life. Regarding the culture of peace, the United Nations Declaration (1998) states: a culture of peace is a set of values, attitudes, traditions, ways of behaving and a way of life that reflects and inspires; First, respect for life and human rights. Second, rejection of all violence in all its forms and commitment to preventing violent conflict by solving root causes through dialogue and negotiation. Third, commitment to fully participate in the process of fulfilling the needs of present and future generations. Fourth, Respect and promote equal rights and opportunities for women and men. Fifth, acceptance of everyone's human rights to freedom of expression, opinion and information. Sixth, respect for the principles of freedom, justice, democracy, tolerance, solidarity, cooperation, pluralism, cultural diversity, dialogue and mutual understanding between nations, between ethnicities, religions, cultures and other groups and individuals (Abidin, 2019). The concept of peace that is applied to each region in Indonesia is in principle the same but has different names. This is influenced by regional conditions, socio-culture. In general, a culture of peace can be done based on:

- $\quad$ Religious values, where each religion teaches its adherents to live peacefully with others.

- The values of local wisdom, because we are a nation that is rich in heritage of noble values that have been tested by the times in realizing a peaceful and harmonious society.

The natives of South Kalimantan are also familiar with peaceful living patterns that have been implemented for a long time. The character of living in harmony and peace since the time when they generally lived along the river also had a strong influence from Islam. Islam is a special character of the banjar community at the same time as the Banjar Kingdom was founded. The Banjar culture is heavily influenced by Islamic values. Even Islam has become the basis of Banjar culture (Hasan, 2009). Historically, the Banjar community has always been identified with Islam. This reflects Islam as a system held by 
the Banjar people. This means that in many ways the behavior of the Banjar people can be referred to in Islamic values. From this trend of reference to social behavior, the function of Islam by the Banjar community has finally become a symbol and identity that distinguishes them. The influence of Islam is reflected in the patterns of daily religious behavior, especially those in everyday terms called rukun-marukun (Daud, 1997). One of the implementations of the peculiarities of the Banjar culture which is inspired by the Islamic religion is the existence of a culture of peace in resolving disputes that occur in society, namely the custom of badamai. The custom of Badamai in the Banjar community is an implementation of the values of Islamic teachings which always teaches the way of peace or ishlah in resolving a dispute (Hasan, 2009).

One form of dispute resolution commonly carried out by the Banjar community is to bring together the two parties assisted by community leaders in order to avoid disputes that could endanger the social order. In the Banjar community, the deliberation mechanism is an alternative effort in finding solutions to solve problems that occur in society. This pattern of dispute resolution in the Banjar community has been rooted in social life for a long time and this pattern has enabled the ancient inhabitants to coexist peacefully even though they came from different areas. If there is a conflict or dispute that is not carried out with the custom of Badamai, it will actually destroy the order of harmony which is a violation of rooted traditional wisdom.

The concept of Badamai adat as a form of dispute resolution has existed since ancient times and has been applied to the Banjar people from generation to generation, even since 1835 it has been stipulated in the Sultan Adam Law (UUSA). The principles of Badamai that exist in UUSA, namely:

- Article 3: Every time I know the village, I will tell the people to agree, astamiyah again between relatives so as not to talk and arguments

- Article 21: Every village, if there is a dispute over the contents of the village, yes, all the villagers, I will tell them to talk about the consensus of the opponent who is the villain of his village, if no one can also talk about ikam bring to the judge

- Article 28: Whoever wants to bahuma in halabiu or other countries or continents then that is not allowed halabiu people or countries or others to raise and no one can recognize the limit without effort and understanding and no one can meharu blue

- Article 29: Any field left by a person for about two seasons or more then becomes a field and there is no sign of its own such as its crop or its pile or its river that lives on its land then it is also carried by the other person and it remains I did not tell the former person to demand more or to sue the judge.

These articles reflect the existence of peaceful methods that must be adopted if a problem arises in society. The pattern applied is to prioritize aspects of deliberation and consensus between the community. The UUSA is a historical document of the Banjar land law which is the source of law for the legal provisions that were applicable in Banjar land in the past. The Sultan Adam Law as a written law that applies Islamic law among residents in the Banjar Kingdom was issued by Sultan Adam al Wasiq Billah (1825-1857) deliberation to avoid disputes and arguments, where the principle of deliberation is emphasized. The more diverse people living in the South Kalimantan region, considering that the current population settlements in South Kalimantan do not only consist of the Banjar people, but also consist of various ethnic groups. Although the river remains the 
most important means of transportation, today the population has also spread to areas relatively far from the riverbanks, but then spread slightly to the slopes of the higher mountains. This is because the low upstream areas provide economic access to local residents encouraging them to go to urban areas even though the real reason is that there are several pockets of the Hulu Sungai area that have cultural reasons to migrate (madam) (Arbain, 2020). This is also marked when roads are built and introduced to be an important means of transportation as well as river transportation, human settlements also occur along the highway, in addition to the old settlements that extend along the river. Along with this development, for a long time there has been an urbanization of suburban areas and villages in South Kalimantan and outside Kalimantan towards the city of Banjarmasin.

The hybrid between the conditions of rural and urban communities who live in one area at this time raises a state of high tolerance in the community environment. The life system of rural communities that has been living for decades with a cultural system that has been inherent from generation to generation reflects an attitude of mutual help, mutual cooperation and a peaceful life between communities that will be faced with a more individual cultural system by urban communities, but the custom of Badamai is still sustainable. In theory, the study of migration and mobility is strong enough to explain that migrants will usually form concentrated settlements among their ethnic groups. This is because later migrants in one village or ethnicity will find and hitchhike with pioneer migrants who have previously settled. Solidarity among ethnic groups living overseas tends to strengthen, because of the human instinct to help and get protection from fellow relatives and fellow villagers. Communal identity is also getting stronger, because it is related to a matter of opportunity, hope is sometimes included in economic resources because it is related to the interests of a survival strategy. The high rate of population migration affects the social fabric of society, apart from being caused by heterogeneous communal entities as well as heterogeneous education and employment in one region. The peri-urban area is located between rural areas on the one hand and urban areas on the other, so that it has hybrid characteristics between urban and rural characteristics (Yunus, 2008). In Banjarmasin, peri urban areas can be identified such as the outskirts of Kertak Hanyar District, Peat District, Sungai Tabuk District, Banjar Regency, and Alalak Berangas District, Barito Kuala Regency as the Peri Urban Area (WPU) of Banjarmasin.

The rate of population growth in the WPU area is followed by the addition of residences close to jobs in the city center. The WPU area was followed by the construction of housing. The impact of rapid population growth is directly proportional to the needs of residential areas. This is one of the factors in the proliferation of new housing complexes in areas directly adjacent to the provincial capital. This is because residential areas in the provincial capital are very unlikely due to limited land. The mushrooming of the construction of new housing complexes has also brought about the movement of people from outside the village. One of the effects of increasing population in an area is the existence of various tribes who then live in a place. Areas that were previously occupied only by local residents became diverse and heterogeneous populations due to the large number of migrants who came from various regions. The new physical development of the areas directly adjacent to the provincial capital has also brought changes to the livelihoods of the people, becoming new physical development areas from the outskirts of the city.

The suburban area is an area known as the urban fringe or peri urban area. The people who live in this area have an important role in the life of the population in the future. 
This area is characterized by being located between two areas that have a urban appearance on the one hand and an area that has a urban appearance on the other. Because rural and urban areas have such complex dimensions of life, it will give rise to a new life order for people in this peri-urban area. The impact that arises from the peri-urban area is the physical expansion of the city such as loss of agricultural land, decreased agricultural productivity, besides that it has a multi-dimensional impact on the social, cultural and economic aspects. One of the impacts of the existence of this peri-urban area is the pattern of dispute resolution that occurs in communities that have become a combination of rural and urban characteristics. It is known that the indigenous people of the Banjar people have a hereditary way to resolve a dispute, namely in a peaceful way, but in its development the indigenous people have mingled with immigrant communities from various ethnic groups. The local wisdom values applied by the people in Banjar Regency and Barito Kuala Regency are still prioritizing peaceful dispute resolution patterns in the community, which is still preserved despite changes in the social order that has become communal heterogeneous, this is because it is a way of going downhill even though the settlement pattern in court is also an option that can be taken by the community. This is especially true for the condition of the people in Banjar Regency which still has the influence of the Banjar Sultanate, where peaceful methods of resolving disputes have been implemented by the Banjar Sultanate.

The pattern of peaceful dispute resolution has not disappeared even though the indigenous population has mingled with the immigrant community, as a result of the increasing number of settlements shifting to the suburban areas. According to Taufik Arbain, that one of the characteristics of Badamai custom is that it will remain attached as long as in one area even though it has become a heterogeneous society because of population growth in the peri-urban area there are still indigenous people of urang banjar, so the badamai custom will continue to be applied. One thing that affects why the custom of Badamai cannot be separated from the urang banjar is because the customary law of Badamai consists of 3 (three) elements, namely (Hasan, 2009):

- Unwritten Elements. In the form of habits that grow and develop in social practice in society. This includes everything that is used to be considered good by the community and will cause reactions from various levels of society if this is violated. Strictly speaking, violators will receive minimal sanctions in the form of criticism from the public.

- Elements Derived From Islamic Law. Includes all provisions of Islamic law and fiqh laws that are maintained and adhered to by the community as a large part of their religious teachings. Islam has become the official religion in the Banjar kingdom and is the only source of law that applies throughout the Banjar Kingdom (Regional Research and Development Agency for South Kalimantan Province, 2005).

- The Elements Origaniting From the Era of The Bnjar Kingdom. As stated in the Sultan Adam Law (1835), the pattern applied in the provisions of the Sultan Adam Law is to prioritize aspects of deliberation and consensus between the people.

- Peaceful dispute resolution in society has now also been regulated in the Village Law Number 6 of 2014 concerning Villages, as regulated in Article 26 (1) states: "The Village Head is tasked with organizing Village Administration, implementing Village Development, Village community development, and Village community 
empowerment ". Furthermore, Article 26 (4) letter k. states: "In carrying out the tasks referred to in paragraph (1), the Village Head is obliged to: resolve community disputes in the Village;”

The Village Government is the foremost unit of service to the community and is a major milestone for the success of all programs. Village Government as the smallest governmental element in the regency / city area. As a leading government unit in service to the community, the village has a strategic role in the government of a district / city. Therefore, strengthening the village is a must that cannot be postponed in an effort to accelerate the realization of community welfare as the goal of regional autonomy. Village society is the subject of development, which is a strength to build the nation if it continues to be improved. The community in the village can become a driving force for strength by increasing the movement, initiative and participation of the village community, preserving and advancing the traditions and culture of the village community as local wisdom to create a village that is advanced, independent and prosperous. Thus the village community has a strategic role in maintaining social unity as part of national resilience and for creating common prosperity. The village head is a figure who can play an important role as a mediator in dispute resolution in his community. This is inseparable from the position of the village head who is generally a figure respected by the community, in addition to Law Number 6 of 2014 concerning Villages which states that the village head is a government leader who has a strong (authoritative) position so that it is expected to be effective. in carrying out the role of a mediator or dispute resolution. The function of the village head as dispute resolution is basically a mediation that has a form between social network mediators and authoritative mediators. Historically, this function has long been known as a village court judge or dorpjustite (Nader and Todd, 1978). The function of the village head as dispute resolution as stipulated in Article 26 (4) letter k of Law Number 6 of 2014 concerning Villages is inseparable from the historical fact that in the past at the village level and customary law communities there was a village court and or customary court. The advantages possessed by the function of the village head as such dispute resolution will be very significant in reducing the flow of cases to the state court which is now very piling up. Many civil disputes and criminal cases or complaint offenses will be more effectively and efficiently resolved by informal courts (customary courts) which are expected to provide restorative justice (Musakkir, 2011).

Conflict resolution should be adapted to the context and background or setting in which the conflict occurs, in this case the universal approach is actually irrelevant to be applied in dealing with conflict problems. There is another form of conflict resolution approach that is often overlooked, namely: local wisdom. In a pluralistic society such as the Indonesian nation, there are a lot of local wisdoms that have great potential in resolving conflicts to create peace. Society is dynamic, and continues to grow increasingly complex. City is something that is closely related to community growth. As a large country with an area and degree of cultural, ethnic and linguistic plurality, Indonesia has a wealth of intellectual traditions including efforts to build peace and develop cultural-based conflict resolution mechanisms (Wahid, 2004). The existence of peace initiatives is carried out using local mechanisms. The models and mechanisms for resolving social conflicts in Indonesia are always supported by 2 (two) sides of the settlement, first the formal and procedural settlement model played by the government and its legal apparatus, the second is the cultural resolution model that is fully played by the local community by using the 
mechanism. customs that have been in effect from generation to generation. The existence of this local value is strengthened by the community's obedience to government officials, which is reflected in the pattern of dispute resolution in rural areas. Figures who have formal positions such as the village head / lurah and other village officials have a respectable position in the community. There is inner satisfaction in the community when their conflicts are resolved by the village head, because they have the authority to regulate community life, trusted people are asked for advice as well as resolve their conflicts and disputes.

In Indonesia, the cooperative dispute resolution mechanism is wide open based on the opportunities provided by Article 130 HIR / 154 RBg, namely "if the two parties appear on the specified day, the district court, mediating between the two, will try to reconcile them". In Law Number 6 of 2004 concerning Villages, this peacemaker figure is played by the Village Head, as stipulated in Article 26 (1) states: "The Village Head has the duty to organize Village Government, carry out Village Development, Village community development, and empower Village communities" . Furthermore, Article 26 (4) letter k. states: "In carrying out the tasks referred to in paragraph (1), the Village Head is obliged to: resolve community disputes in the Village.” The existence of an arrangement regarding the obligation of the village head to resolve disputes at the village level is very relevant to the contents of the regulation in Article 21 of the Sultan Adam Law which also requires community leaders to be the ones who will help resolve disputes. The pattern of peace which has been rooted for generations for the banjar community to date has made the implementation of the provisions of Article 26 paragraph (4) letter k of the Village Law very easy for the community to accept. Because in principle, the dispute resolution patterns contained in the Sultan Adam Law and the Village Law have similarities. This will in fact further strengthen the peace pattern institutions in the banjar community because at this time it has been supported by an obligation for the village head to resolve community disputes in the village. The integration between the environmental aspects of a peaceloving community with the tradition of coexistence and the role of the Village Government, in this case the village head or other village apparatus, is a strengthening of the implementation of a peaceful dispute resolution system in the banjar community. Settlement of disputes in the community which is carried out with the help of a mediator from the village head or village officials tends to use the interest based negotiation type of negotiation, the basis of which is that with this approach the interests of all parties can be represented. The objective of the mediation process and interest based negotiation is an agreement that satisfies the needs and interests and formulates options and alternatives in accordance with those interests. The village head or village apparatus assists the parties in reaching an agreement with a pattern of transitioning from positional negotiation to interest based negotiation in achieving an integrated solution that is reasonable and in accordance with the needs.

\section{Conclusion}

The characteristics of dispute resolution in a wetland environment through the concept of badamai are identical to the pattern of dispute resolution through negotiation and mediation as regulated in Law Number 30 of 1999 concerning Arbitration and Alternative Dispute Resolution. The integration between the environmental aspects of a 
peace-loving community with the tradition of coexistence and the role of the Village Government, in this case the village head, is a factor that strengthens the implementation of a peaceful dispute resolution system in the banjar community. This strengthening is the integration that fits between the environmental aspects of wetlands (Nature), Culture (Badamai) and Village Government (Government) or the ABG concept with an interestbased model approach..

\section{Recommendation}

Strengthening the custom of badamai in the form of recommendations for the preparation of an academic paper for village regulations on dispute resolution based on local wisdom (badamai). The pattern of dispute resolution in a peaceful manner should be maintained by the community in their daily life alongside the customs of other communities.

\section{References}

1. $\quad$ Abidin, Z. (2019). Pentingnya Budaya Damai dalam Kehidupan Sehari-Hari. Radar Sulteng, can be accessed on https://radarsulteng.id/pentingnya-budaya-damai-dalam-kehidupan-sehari-hari/

2. Arbain, T. (2020). Memahami Kependudukan (Perspektif Kebijakan Publik, Sosiologi dan Pembangunan Wilayah). Banjarmasin, Pustaka Banua_Pusat Studi Kebijakan Publik Universitas Lambung Mangkurat.

3. Daud, A. (1997). Islam dan Masyarakat Banjar : Deskripsi dan Analisa Kebudayaan Banjar. Jakarta, PT. RajaGrafindo Persada

4. $\quad$ Fetterman, D.M. (1998). Ethnography Step by Step. London, Sage Publishing.

5. Hasan, A. (2009). Adat Badamai: Interaksi Hukum Islam dan Hukum Adat pada Masyarakat Banjar. Banjarmasin, Antasari Press.

6. $\quad$ Musakkir. (2011). Penerapan Prinsip Keadilan Restoratif terhadap Penyelesaian Perkara Pidana dalam Perspektif Sosiologi Hukum, Professor Inauguration Speech, Faculty of Law, UNHAS, 12 July 2011.

7. $\quad$ Nader, L. \& Todd, H.F. (1978). The Disputing Process-Law in Ten Societes. New York, Columbia University Press.

8. $\quad$ Regional Research and Development Agency of South Kalimantan Province. (2005). Urang Banjar and its Culture. Banjarmasin, Pustaka Banua.

9. Wahid, A. (2004). Presentasi Peluncuran Program Balai Mediasi Desa. Jakarta, Kerjasama LP3ESNZAID.

10. Yunus, H.S. (2008). Dinamika Wilayah Peri Urban Determinan Masa Depan Kota. Yogyakarta, Pustaka Pelajar. Creative Commons Attribution - Non Commercial - No Derivatives 4.0 International License. 